\title{
Mono-and Binuclear Cobalt(II) Mixed Ligand Complexes of 2,2'-Bipyridine and Ethylenediamine: Synthesis, Characterization and Biological Application
}

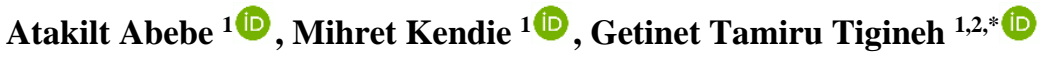 \\ 1 Department of Chemistry, Science College, Bahir Dar University, PO Box 79, Ethiopia; atakiltabebe1@ gmail.com (A.A.); \\ kendiemihret06@gmail.com (M.K.); \\ 2 Department of Chemistry and Research Institute of Physics and Chemistry, Jeonbuk National University, Jeon-Ju, \\ Jeollabuk-do, 54896, Republic of Korea \\ * Correspondence: getsh2007@gmail.com (G.T.T.);
}

Scopus Author ID 56203253700

Received: 14.03.2021; Revised: 1.05.2021; Accepted: 3.05.2021; Published: 10.06.2021

\begin{abstract}
Antibiotic resistance of pathogens to the current commercially available drugs is a serious problem. To curve this problem, the discovery of active compounds with a new mode of action is insistent. In line with this, we report two new complexes; mononuclear $\left[\mathrm{Co}\left(\mathbf{L}_{\mathbf{1}}\right)_{2}\left(\mathbf{L}_{\mathbf{2}}\right)\left(\mathrm{H}_{2} \mathrm{O}\right)\right] \mathrm{Cl}_{2}$ and binuclear $\left[\mathrm{Co}_{2}\left(\mathbf{L}_{\mathbf{1}}\right)_{4}\left(\mathbf{L}_{2}\right)\left(\mathrm{H}_{2} \mathrm{O}\right)_{2}\right] \mathrm{Cl}_{4}$ using precursor complex, $\left[\mathrm{Co}\left(\mathbf{L}_{\mathbf{1}}\right)_{2}\left(\mathrm{H}_{2} \mathrm{O}\right)_{2}\right] \mathrm{Cl}_{2}$, synthesized before; where $\mathbf{L}_{1}$ : 2,2'-bipyridine and $\mathbf{L}_{2}$ : ethylenediamine. The precursor complex was prepared from $\mathrm{CoCl}_{2} \cdot 6 \mathrm{H}_{2} \mathrm{O}$ and $\mathbf{L}_{1}$ in ethanol, treated with a different mole of $\mathbf{L}_{2}$ under optimized reaction conditions to give the corresponding mono-and binuclear cobalt(II) mixed ligand complexes. These complexes were characterized using the spectroscopic technique (ICP-OES, UV-Vis, FT-IR) and physicochemical methods (chloride determination, thermal analysis, and conductance measurement). Their antibacterial activities were also tested against two Gram-negative (Escherichia coli (E. coli) and Klebsiella pneumoniae ( $K$. pneumoniae)) and two Gram-positive (Staphylococcus aureus (S. aureus), Streptococcus pyogenes (S. pyogenes)) bacteria using the disc diffusion method. The new complexes showed better activities against $K$. pneumoniae than the reference Gentamycin. Furthermore, $\left[\mathrm{Co}\left(\mathbf{L}_{1}\right)_{2}\left(\mathbf{L}_{2}\right)\left(\mathrm{H}_{2} \mathrm{O}\right)\right] \mathrm{Cl}_{2}$ demonstrated better activity than Gentamycin against $S$. aureus and E. coli.
\end{abstract}

Keywords: 2,2-bipyridine; ethylenediamine; cobalt(II) complexes; antibacterial activity.

(C) 2021 by the authors. This article is an open-access article distributed under the terms and conditions of the Creative Commons Attribution (CC BY) license (https://creativecommons.org/licenses/by/4.0/).

\section{Introduction}

In coordination with suitable ligands, it is possible to impose a set of desired properties on transition metals for specific applications. Tailoring types of ligands in complexes govern properties such as the stability of different oxidation states, solvophilicity, and electronic properties of the metal ions $[1,2]$. The later properties play significant roles in the medicinal properties of transition metal coordination compounds. Recognizing this, pharmaceutical industries have been considering solutions for their effort to circumvent the proliferation of commercially available drugs-resistant microbes. [3,4].

This has been done by designing transition metal complexes in a way that was effectively targeting the DNA of the microbe through a series of interactions, such as stacking interaction associated with the interaction of aromatic heterocyclic groups between the base pairs, hydrogen bonding, and Vander Waals interactions [5-7]. In this context, active compounds 
from ligands such as 2,2'-bipyridine, 4,4'-bipyridine, 1,10-Phenanthroline, and their transition metal complexes have been reported by the scientific community as part of the solution [8-15]. In particular, the emerging antibacterial and antifungal activities, along with interesting bioinorganic chemistry of cobalt(II) complexes, have recently caught the attention of many researchers [16-19]. However, there is no report on Co(II) complexes containing 2,2-pyridine mixed with ethylenediamine, which is active against Gram-negative bacteria.

The ligand 2,2'-bipyridine, among heterocyclic ligands, is a superb chelating bidentate ligand (Figure 1a). Its $\sigma$-donation is complemented by the $\pi$-acceptor ability giving the complex greater stability [20, 21]. This allows metal complexes to have a well-defined spatial arrangement [22] and, in turn, greater antimicrobial activities [23].

Ethylenediamine (Figure 1b) is a strong aliphatic base widely used in the pharmaceutical industries and has biological actions [24]. The two nitrogen atoms of ethylenediamine are active in coordination and, interestingly, act as chelating, bridging, and mono-dentate, with $\mathrm{NH}_{2}$ tail, ligand-based on the synthesis protocol [25-27]. Therefore, in this study, the structural investigation and biological activities of new cobalt complexes in a 1:1 and 1:2 L2 to precursor complex are examined, respectively. It is found that mixed-ligand complexes have an advantage in that the respective bioactivities of the uncoordinated ligands and metal ions are combined, which could make them more potent antimicrobial agents [28].

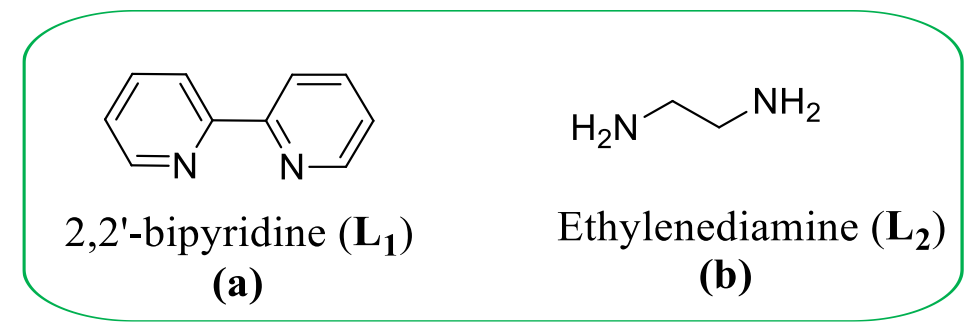

Figure 1. Ligands used in this work.

\section{Materials and Methods}

\subsection{List of chemicals.}

The chemicals used were cobalt chloride hexahydrate (Blulux Laboratories Pvt.Ltd.01), ethylenediamine, 2,2'-bipyridine (Clent Chemical CO., LTD), $\mathrm{AgNO}_{3}$ (Blulux Laboratories(P), ltd-121 001), $\mathrm{HNO}_{3}$ (65\%, Lobachemie), $\mathrm{HClO}_{4}$ (60\%, Sisco), $\mathrm{H}_{2} \mathrm{SO}_{4}$ (98\%, Lobachemie), $\mathrm{KBr}$ ( Blulux Laboratories (p) ltd.-121 001), solvents like deionized water, methanol (India) Pvt. Ltd.), ethanol (Himedia laboratory, Pvt, Ltd, India), acetone (Germen, dutch, polish), acetonitrile (India, Pvt, Ltd.), dichloromethane (UN1593), ethyl acetate (Lobachemie), and diethyl ether (Tokyo chemical industry UK Ltd.), DMSO (Lobachemie), chloroform, silica gel, Mueller Hinton agar.

\subsection{Instruments.}

The molar conductance was measured using a $10^{-3} \mathrm{M}$ solution of each complex in deionized water with a Bante901P portable $\mathrm{pH} /$ conductivity/TDS meter at room temperature. The electronic spectra were recorded in the 200-800 nm regions on Sanyo SP65 UV/Vis spectrophotometer. IR spectra were recorded using $\mathrm{KBr}$ pellets in the $4000-400 \mathrm{~cm}^{-1}$ region on the Perkin Elmer FT-IR spectrometer. Cobalt content was determined by Perkin Elmer, Optima 8000 VHF ICP-OES spectrometer, digesting each synthesized complex in concentrated nitric acid, sulphuric acid, and perchloric acid diluting them using deionized water. The calibration 
curve of cobalt in its formed complex was constructed using a series of concentrations of the standard solutions and then plotting the absorbance as a function of their corresponding concentrations. A linear relationship was found between the measured values of absorbance and the concentrations of the metal. A high correlation coefficient value was obtained (0.9998). The complexes' melting point or decomposition temperatures were measured with Stuart SMP30, UK digital melting point apparatus.

\subsection{Methods.}

\subsubsection{Synthesis.}

New mono and binuclear Cobalt(II) complexes containing 2,2-bipyridine ( $\left.\mathrm{L}_{1}\right)$ and ethylenediamine $\left(\mathrm{L}_{2}\right)$ were synthesized under optimized reaction conditions (Scheme 1).

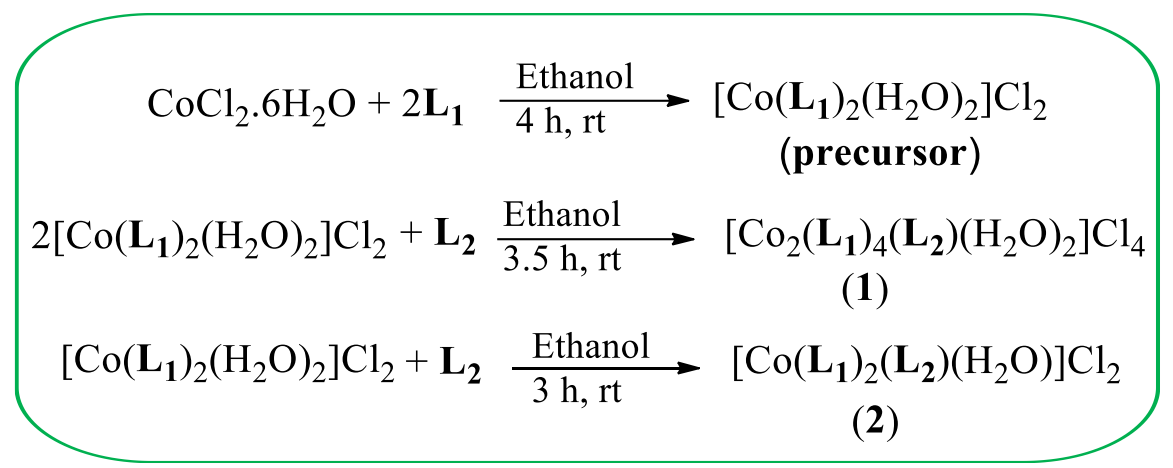

Scheme 1. Synthesis strategy of Co(II)-complexes.

\subsubsection{Diaquabis (2,2'-bipyridine) cobalt (II) chloride $\left[\mathrm{Co}\left(\mathrm{L}_{1}\right)_{2}\left(\mathrm{H}_{2} \mathrm{O}\right)_{2}\right] \mathrm{Cl}_{2}\{$ Precursor $\}$.}

Following a method of Jaeger et al. [29], a solution of 2,2'-bipyridine (1 g, $6.4 \mathrm{mmol})$ in $30 \mathrm{ml}$ ethanol was filled in a burette and added dropwise to a magnetically stirred ethanolic solution of $\mathrm{CoCl}_{2} .6 \mathrm{H}_{2} \mathrm{O}(0.76 \mathrm{~g}, 3.2 \mathrm{mmol})$ in $250 \mathrm{~mL}$ round bottom flask. The mixture was stirred for $4 \mathrm{~h}$ at room temperature. The Vine red homogeneous solution was obtained. The solvent was removed using a rotary evaporator. The reddish-brown powder was collected and washed three times with acetone to remove if any unreacted 2,2'-bipyridine was present. It was then re-crystallized from ethanol (yield, $1.47 \mathrm{~g} ; 96.1 \%$ ).

2.3.1.2. Aquabis (2,2'-bipyridine) cobalt (II)- $\mu$-ethylenediamine aquabis(2,2'- bipyradine) cobalt (II) chloride $\left[\mathrm{Co}_{2}\left(\mathrm{~L}_{1}\right)_{4}\left(\mathrm{~L}_{2}\right)\left(\mathrm{H}_{2} \mathrm{O}\right)_{2}\right] \mathrm{Cl}_{4}\{1\}$.

While an aqueous solution of precursor complex $(0.787 \mathrm{~g} 1.645 \mathrm{mmol})$ is stirred magnetically at room temperature, an aqueous solution of ethylenediamine $55 \mu \mathrm{L}(0.049 \mathrm{~g}$ $0.824 \mathrm{mmol}$ ) in $30 \mathrm{ml}$ ethanol was added from a dropping burette. The mixture was allowed to stir for $3.5 \mathrm{~h}$ at room temperature. Brown solution was obtained and removed from a stirring plate. The solvent was removed under vacuum at room temperature. Vandyke brown powder was collected, washed several times with acetone, dried, and weighed (yield, $0.79 \mathrm{~g} ; 97.9 \%$ ).

2.3.1.3. Aquabis (2,2'-bipyradine) ethylenediamine cobalt(II) chloride $\left[\mathrm{Co}\left(\mathrm{L}_{1}\right)_{2}\left(\mathrm{~L}_{2}\right)\left(\mathrm{H}_{2} \mathrm{O}\right)\right] \mathrm{Cl}_{2}$

To an ethanolic solution of complex $1(0.39 \mathrm{~g}, 0.824 \mathrm{mmol})$ in $250 \mathrm{~mL}$ round-bottomed flask stirred magnetically with stirring plate at room temperature, a solution of ethylenediamine (55 $\mu \mathrm{L}, 0.049 \mathrm{~g}, 0.824 \mathrm{mmol}$ ) in $30 \mathrm{~mL}$ ethanol was added from a dropping burette in to round 
bottom flask. The mixture was allowed to stir for $3 \mathrm{~h}$ at room temperature. Then the dark-brown homogeneous solution was obtained and removed from the stirring plate. Finally, the solvent from the solution was removed by rotary evaporator, and the bronze solid was collected, washed three times with acetone, dried, and weighed (yield, $0.45 \mathrm{~g} ; 95.2 \%$ ).

\subsection{Antibacterial activity testing.}

The in vitro biological activity of ligand and metal complexes was tested against four bacterial strains such as Staphylococcus aureus and Streptococcus pyogenes as Gram +ve bacteria while Escherichia coli and Klebsiella pneumoniae as Gram -ve bacteria. The screening effect was carried out using a disk diffusion technique in the presence of Muller-Hinton Agar nutrient as the medium. The test solution was filled in the well, and the plates were inoculated at $37^{\circ} \mathrm{C}$ for $24 \mathrm{~h}$. During this time, the growth of the inoculated microorganisms was affected, and then the developed inhibition zones on the plates were measured. The antibacterial activity of each compound was associated with that of standard antibiotics (Gentamycin). Deionized water was used as a control under the same conditions for each organism, and no activity was found. The activity results were calculated as a mean of triplicates. The minimum inhibitory concentration (MIC) against each bacterium was determined by preparing aqueous solutions of different concentrations of the complexes by serial dilution (700, 500, 300, 250, 200, and 150 and $100 \mathrm{mg} / \mathrm{L})$. The antibacterial tests were carried out at Bahir Dar University, Department of Biology, Microbiology Laboratory, Bahir Dar, Ethiopia.

\section{Results and Discussion}

The precursor complex, complexes 1 and 2 are stable in air and moisture insensitive. They are soluble in polar solvents, and the solubility was decreased with decreasing the polarity of the solvents. The observation of new colored products in each reaction and the difference in the thermal analysis result of products manifested the formation of complexes. Furthermore, the gravimetric chloride determination result revealed the expected quantitative amount of chloride in the outer sphere of the complexes, which is later confirmed by conductivity measurements (Table 1).

\subsection{Electrical conductivity.}

The electrical conductance measurement results of the complexes revealed the electrolytic nature of the complexes indicating the presence of chloride ions as counter anions (Table 1). However, lower conductivity than expected from 1:4 cation to anion composition of complexes 1 was speculated to be as a consequence of its larger mass and surface area of the cation, which slowed the mobility and in turn decreased its kinetic energy imparted by the electric field from the measurement instrument [30, 31].

\subsection{Cobalt content measurement}

A close agreement between the measured and calculated amount of the metal-based on the proposed formula of the complex gives a clue of the formation of the complexes. Accordingly, the ICP-OES result showed the anticipated amount of cobalt in complexes, which confirms the achievement of the intended complexes (Table 1). 
Table 1. Analytical data of $\mathrm{Co}(\mathrm{II})$ complexes.

\begin{tabular}{|c|c|c|c|c|}
\hline \multirow[t]{2}{*}{ Complexes } & \multirow{2}{*}{$\begin{array}{l}\text { Melting/decomposition } \\
\text { point }\left({ }^{\circ} \mathbf{C}\right)\end{array}$} & \multicolumn{2}{|c|}{$\begin{array}{c}\text { Elemental estimation calculated } \\
(\text { found })(\%)\end{array}$} & \multirow{2}{*}{$\begin{array}{c}\text { Molar } \\
\text { Conductivity } \\
\left(\mathrm{Scm}^{2} \mathrm{~mol}^{-1}\right)\end{array}$} \\
\hline & & Co & $\mathbf{C l}$ & \\
\hline$\left[\mathrm{Co}\left(\mathbf{L}_{1}\right)_{2}\left(\mathrm{H}_{2} \mathrm{O}\right)_{2}\right] \mathrm{Cl}_{2}$ & $255(d)$ & $12.32(12.17)$ & $15.20(14.93)$ & 184 \\
\hline$\left[\mathrm{Co}_{2}\left(\mathbf{L}_{1}\right)_{4}\left(\mathbf{L}_{2}\right)\left(\mathrm{H}_{2} \mathrm{O}\right)_{2}\right] \mathrm{Cl}_{4}$ & $200(\mathrm{~d})$ & $6.33(6.01)$ & $7.22(6.63)$ & 201 \\
\hline$\left[\mathrm{Co}\left(\mathbf{L}_{1}\right)_{2}\left(\mathbf{L}_{2}\right)\left(\mathrm{H}_{2} \mathrm{O}\right)\right] \mathrm{Cl}_{2}$ & $125-127(\mathrm{~m})$ & $11.30(10.60)$ & $13.64(13.30)$ & 160 \\
\hline
\end{tabular}

\subsection{FT-IR spectra.}

A careful comparison between FT-IR spectra of the ligands and their complexes gave an insight into whether coordination has taken place or not [32]. Accordingly, the appearance of a non-ligand new broad peak in all complexes between $3398-3446 \mathrm{~cm}^{-1}$ confirmed the coordination of water. The characteristic stretching bands in free ligand 2,2'-bipyridine at 3055 $\mathrm{cm}^{-1}(\mathrm{~s}), 1577 \mathrm{~cm}^{-1}(\mathrm{~s}), 1449 \mathrm{~cm}^{-1}(\mathrm{~s})$ and $1246 \mathrm{~cm}^{-1}(\mathrm{~s})$ assigned for $v_{\mathrm{C}-\mathrm{H}}, v_{\mathrm{C}=\mathrm{N}}, v_{\mathrm{C}=\mathrm{C}}$, and $v_{\mathrm{C}-\mathrm{N}}$ respectively (Figure 2a). After complexation, the bands of $v_{\mathrm{C}=\mathrm{N}}\left(1577 \mathrm{~cm}^{-1}\right)$ and $\delta_{\mathrm{C}-\mathrm{H}}\left(987 \mathrm{~cm}^{-}\right.$ $\left.1,753 \mathrm{~cm}^{-1}\right)$ of 2,2'-bipy ligand shift to higher values around at $(1596,1015$, and 777$) \mathrm{cm}^{-1}$, indicating that the chemical bonds are formed between Co(II) ion and nitrogen atoms of 2,2'bipy in the complexes [33]. The IR spectra of Complex 1 and 2 resemble each other due to the similarity in types of connectivity. However, the binuclear complex manifested stronger intensity of the coordination sensitive ring stretching modes of 2,2'-bipy peaks at 1596, 1015, $777 \mathrm{~cm}^{-1}$, which are attributed to an increase in the number of 2,2'-bipy in complex 1 . Furthermore, complex 1 showed a new peak at $1700 \mathrm{~cm}^{-1}$, which is absent in complex 2. The former confirmed the formation of the binuclear complex.
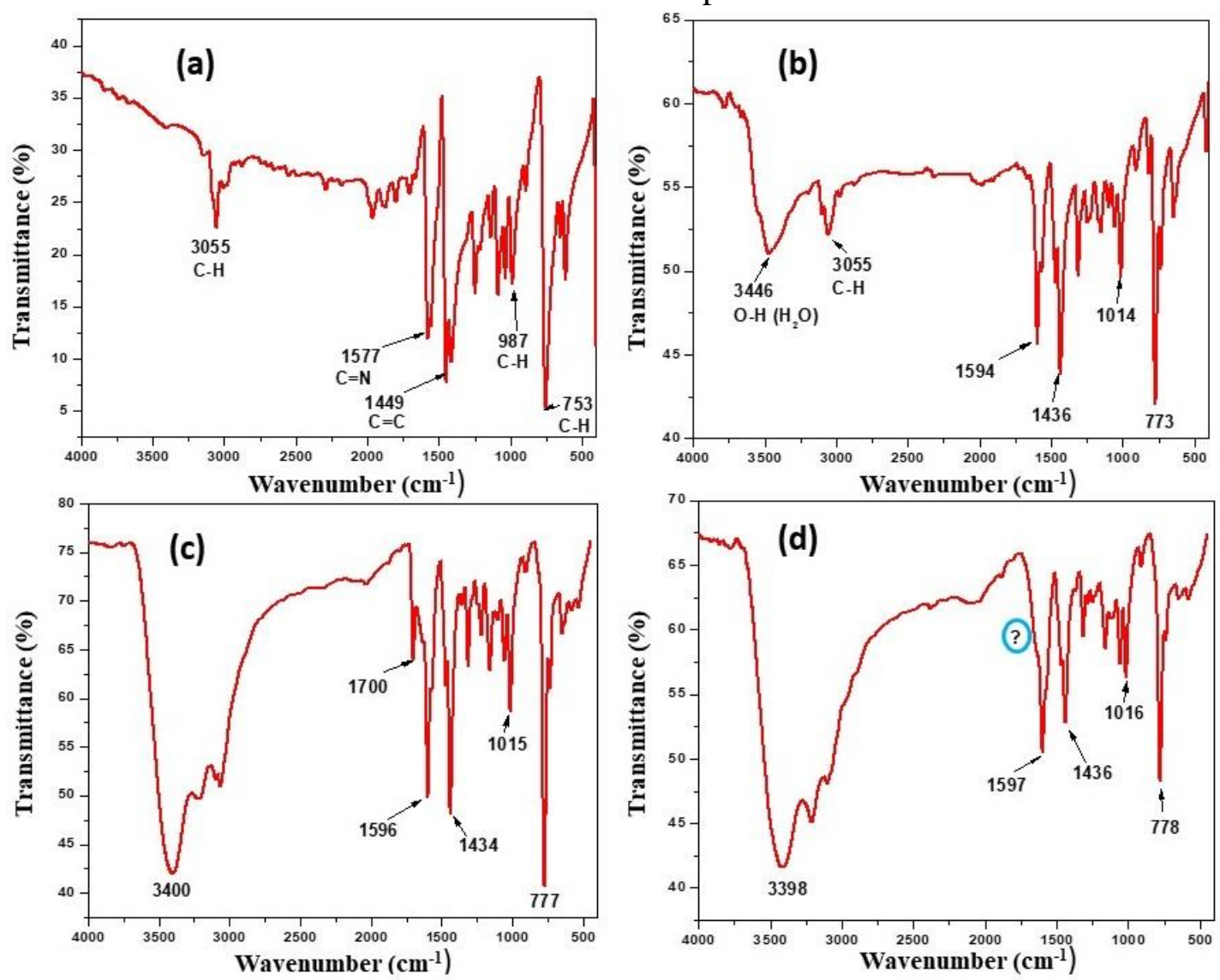

Figure 2. FT-IR spectra of (a) 2,2'-bipy; (b) $\left[\mathrm{Co}\left(\mathrm{L}_{1}\right)_{2}\left(\mathrm{H}_{2} \mathrm{O}\right)_{2}\right] \mathrm{Cl}_{2}$; (c) $\left[\mathrm{Co}_{2}\left(\mathrm{~L}_{1}\right)_{4}\left(\mathrm{~L}_{2}\right)\left(\mathrm{H}_{2} \mathrm{O}\right)_{2}\right] \mathrm{Cl}_{4}$; (d) $\left[\mathrm{Co}\left(\mathrm{L}_{1}\right)_{2}\left(\mathrm{~L}_{2}\right)\left(\mathrm{H}_{2} \mathrm{O}\right)\right] \mathrm{Cl}_{2}$. 


\subsection{UV-Visible spectra.}

The spectral data of the compounds are presented in Figure 3 and Table 2. The ligand 2,2'-bipyridine showed sharp absorption bands at $233 \mathrm{~nm}$ and $280 \mathrm{~nm}$, which are attributed to $\pi \rightarrow \pi^{*}(\mathrm{C}=\mathrm{C})$ and $\mathrm{n} \rightarrow \pi^{*}(\mathrm{C}=\mathrm{N})$ transitions Figure 3(a). However, upon coordination, the bands in 2,2'-bipy showed a redshift for all synthesized complexes, which confirms coordination of 2,2'-bipy ligand to the central metal. The expected d-d transition bands are not clearly observed at working solution concentration. It is not surprising that $\mathrm{d}-\mathrm{d}$ transition is spin allowed, but Laporte forbidden transition, due to this, the bands are not observable at a lower concentration. However, an attempt made to run the measurement at a higher concentration visualized the existence of the absorption band at a higher wavelength. The bands resemble the d-d transition bands of octahedral complex and are assigned for ${ }^{4} \mathrm{~T}_{1} \mathrm{~g}(\mathrm{~F}) \rightarrow{ }^{4} \mathrm{~T}_{1} \mathrm{~g}(\mathrm{P}),{ }^{4} \mathrm{~T}_{1} \mathrm{~g}(\mathrm{~F}) \rightarrow{ }^{4} \mathrm{~A} 2 \mathrm{~g}(\mathrm{~F})$ and ${ }^{4} \mathrm{~T}_{1} \mathrm{~g}(\mathrm{~F}) \rightarrow{ }^{4} \mathrm{~T}_{2} \mathrm{~g}(\mathrm{~F})$ transitions $[1,12,18]$.
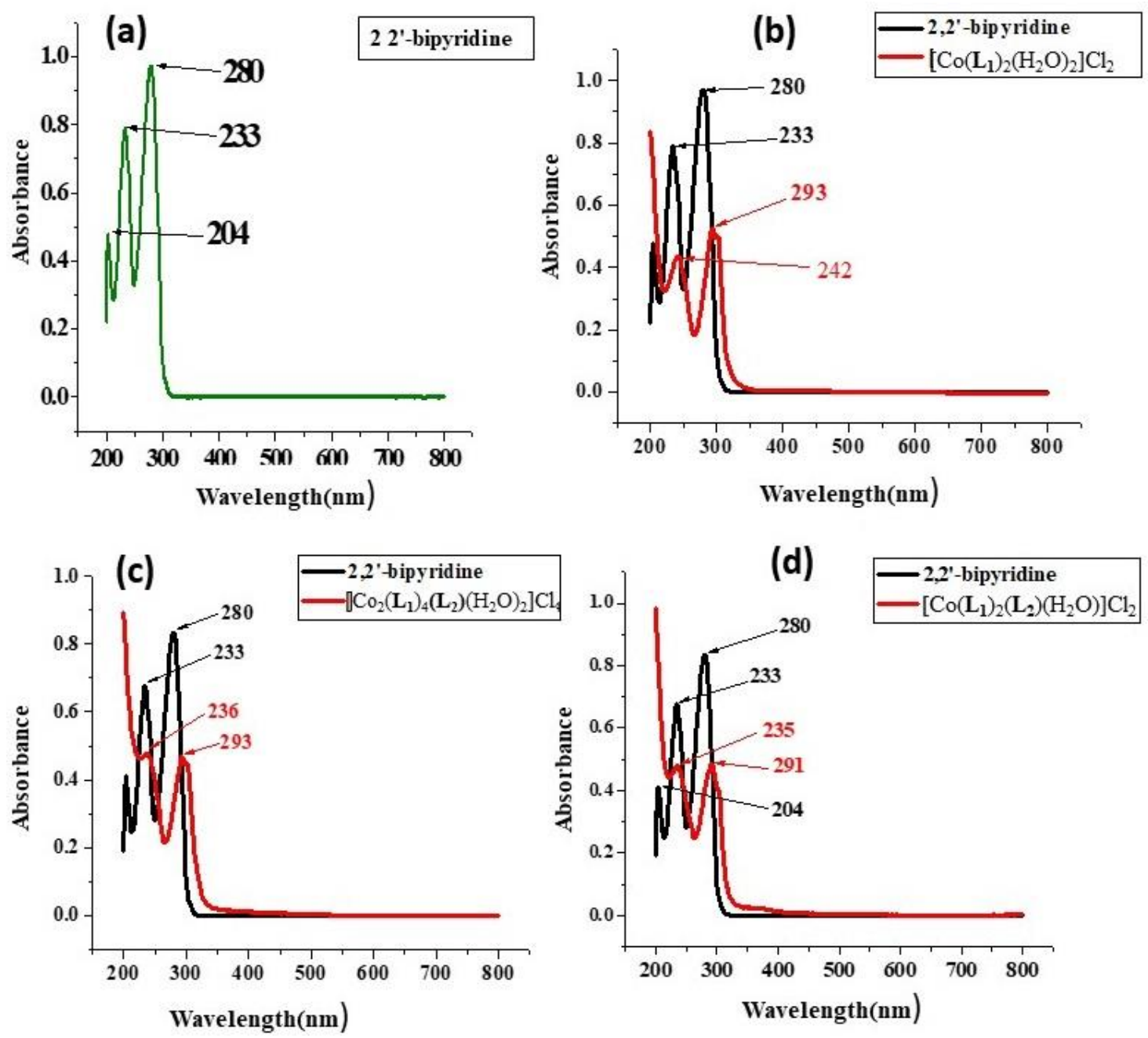

Figure 3. UV-Vis spectra of ligand and complexes.

Table 2. Electronic spectral data of the metal salt, ligands, and complexes.

\begin{tabular}{|c|c|c|c|}
\hline Compound & Solvent & $\begin{array}{l}\text { Absorption } \\
\text { band in }(\mathrm{nm})\end{array}$ & Type of transition \\
\hline $\mathrm{CoCl}_{2} \cdot \mathrm{H}_{2} \mathrm{O}$ & Deionized water & $223,303,505$ & d-d transition \\
\hline Ethylenediamine & Deionized water & 202 & $\mathrm{n} \rightarrow \delta^{*}(\mathrm{~N}-\mathrm{C})$ \\
\hline 2,2'-bipyridine & Methanol & $202,233,280$ & $\pi \rightarrow \pi^{*}(\mathrm{C}=\mathrm{N}), \pi \rightarrow \pi^{*}(\mathrm{C}=\mathrm{C}), \mathrm{n} \rightarrow \pi^{*}(\mathrm{C}=\mathrm{N})$ \\
\hline$\left[\mathrm{Co}\left(\mathbf{L}_{1}\right)_{2}\left(\mathrm{H}_{2} \mathrm{O}\right)_{2}\right] \mathrm{Cl}_{2}$ & Deionized water & 242,293 & $\pi \rightarrow \pi^{*}(\mathrm{C}=\mathrm{C}), \mathrm{n} \rightarrow \pi^{*}(\mathrm{C}=\mathrm{N})$ \\
\hline$\left[\mathrm{Co}_{2}\left(\mathbf{L}_{\mathbf{1}}\right)_{4}\left(\mathbf{L}_{\mathbf{2}}\right)\left(\mathrm{H}_{2} \mathrm{O}\right)_{2}\right] \mathrm{Cl}_{4}$ & Deionized water & $\begin{array}{l}237,293, \\
545,653,748\end{array}$ & $\begin{array}{l}\pi \rightarrow \pi^{*}(\mathrm{C}=\mathrm{C}), \mathrm{n} \rightarrow \pi^{*}(\mathrm{C}=\mathrm{N}) \\
\left({ }^{4} \mathrm{~T}_{1 \mathrm{~g}}(\mathrm{~F}) \rightarrow{ }^{4} \mathrm{~T}_{1 \mathrm{~g}}(\mathrm{P})\right),\left({ }^{4} \mathrm{~T}_{1 \mathrm{~g}}(\mathrm{~F}) \rightarrow{ }^{4} \mathrm{~A}_{2 \mathrm{~g}}(\mathrm{~F})\right), \\
\left({ }^{4} \mathrm{~T}_{1 \mathrm{~g}}(\mathrm{~F}) \rightarrow{ }^{4} \mathrm{~T}_{2 \mathrm{~g}}(\mathrm{~F})\right)\end{array}$ \\
\hline
\end{tabular}




\begin{tabular}{l|l|l|l} 
Compound & Solvent & $\begin{array}{l}\text { Absorption } \\
\text { band in }(\mathbf{n m})\end{array}$ & Type of transition \\
\hline$\left[\mathrm{Co}\left(\mathbf{L}_{1}\right)_{2}\left(\mathbf{L}_{2}\right)\left(\mathrm{H}_{2} \mathrm{O}\right)\right] \mathrm{Cl}_{2}$ & Deionized water & 235,291 & $\pi \rightarrow \pi^{*}(\mathrm{C}=\mathrm{C}), \mathrm{n} \rightarrow \pi^{*}(\mathrm{C}=\mathrm{N})$ \\
& & $496,628,724$ & $\begin{array}{l}\left({ }^{4} \mathrm{~T}_{1 \mathrm{~g}}(\mathrm{~F}) \rightarrow{ }^{4} \mathrm{~T}_{1 \mathrm{~g}}(\mathrm{P})\right),\left({ }^{4} \mathrm{~T}_{1 \mathrm{~g}}(\mathrm{~F}) \rightarrow{ }^{4} \mathrm{~A}_{2 \mathrm{~g}}(\mathrm{~F})\right), \\
\left({ }^{4} \mathrm{~T}_{1 \mathrm{~g}}(\mathrm{~F}) \rightarrow{ }^{4} \mathrm{~T}_{2 \mathrm{~g}}(\mathrm{~F})\right)\end{array}$
\end{tabular}

Based on the aforementioned analytical and spectral data, octahedral geometry was proposed for both complexes (Figure 4).

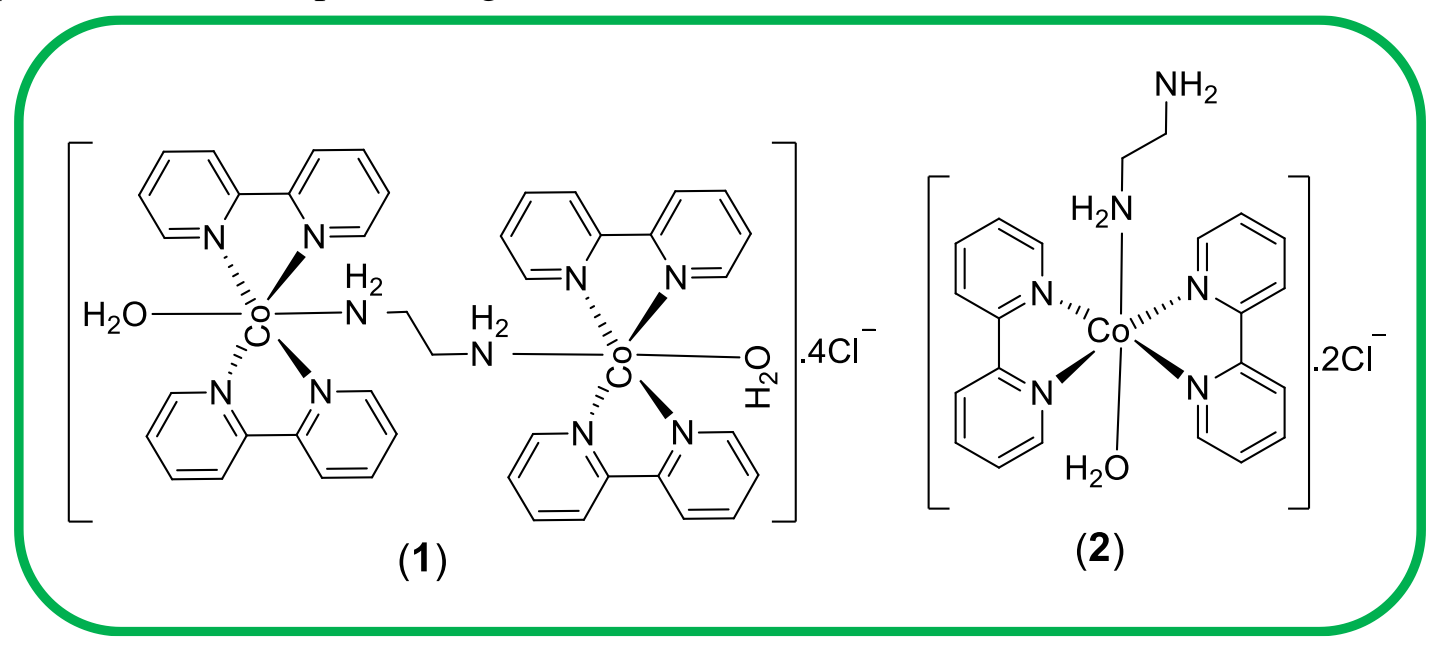

Figure 4. Proposed structures of complexes.

\subsection{Antibacterial activity testing.}

Methanol and deionized water were the working solvents and showed no antibacterial activity on the tested microbes. $\mathrm{CoCl}_{2} \cdot 6 \mathrm{H}_{2} \mathrm{O}$ and ethylenediamine exhibited moderate antibacterial activity against the tested bacterial strain. However, 2,2'-bipyridine demonstrated the highest antibacterial activity even compared to the commercial drug. Due to its planarity and extended conjugation, 2,2'-bipyridine can intercalate with double strands of the forming $\pi$ $\pi$ interactions with base pairs DNA, consequently inhibiting replication [34, 35]. Nevertheless, it could not be directly used for medicinal applications due to its toxicity caused by inhibiting metalloenzymes via its chelating nitrogen atoms. Nonetheless, the toxicity could be avoided by coordinating with transition metals. Co(II) complexes of 2,2-bipy were synthesized based on this concept, and both complexes showed comparable antibacterial activities to Gentamicin. The observed antibacterial activity could be explained based on Overton's concept [36] and Tweedy's chelation theory [37].

Furthermore, the comparative study with the corresponding $\mathrm{Co}$ (II) complexes from our group revealed that the newly synthesized complexes manifested comparable or even better antibacterial activity than previously reported metal complexes Table 3. Exceptionally, the mononuclear complex exhibited higher antibacterial activity against most tested bacteria than the corresponding Phenanthroline-containing mixed ligand complexes.

The comparative inhibition of the synthesized complexes with the reference Gentamycin was indicated by the percent activity indexes. The results of in vitro antimicrobial activities were compared with the commercially available antimicrobial agents Gentamycin. Both complexes 1 and 2 inhibited the growth of $K$. pneumoniae better than Gentamycin by $4.7 \%$ and $27.3 \%$, respectively. Complex 2 also shows better activity than Gentamycin on $S$. aureus and E. coli by $4.5 \%$ and $0.3 \%$, respectively Table 4 and Figure 5. Overall, both complexes were found to be water-soluble along with their promising antibacterial activities, 
indicating their compatibility with normal human physiological systems and their potential for human medication after in vivo cytotoxicity tests.

Table 3. Antibacterial test results of metal salt, ligands, complexes, and literature values.

\begin{tabular}{|c|c|c|c|c|c|}
\hline \multirow[t]{2}{*}{ Compounds } & \multicolumn{4}{|c|}{ Antibacterial activity (mean IZ diameter $(\mathbf{m m}) \pm \mathrm{SD})$} & \multirow[b]{2}{*}{ Ref. } \\
\hline & S. aureus & $\begin{array}{l}S . \\
\text { pyogenes }\end{array}$ & $\begin{array}{l}\text { K. } \\
\text { pneumoniae }\end{array}$ & E.coli & \\
\hline 2,2'-bipy & $30.20 \pm 0.15$ & $35.40 \pm 0.25$ & $40.50 \pm 0.14$ & $32.00 \pm 0.23$ & \\
\hline $\mathrm{CoCl}_{2} \cdot 6 \mathrm{H}_{2} \mathrm{O}$ & $11.00 \pm 0.00$ & $11.10 \pm 0.20$ & $9.00 \pm 0.30$ & $12.20 \pm 0.00$ & \\
\hline en & $10.20 \pm 0.00$ & $13.20 \pm 0.21$ & $12.00 \pm 0.00$ & $9.00 \pm 0.00$ & \\
\hline Gentamycin & $28.30 \pm 0.12$ & $30.50 \pm 0.23$ & $25.30 \pm 0.24$ & $29.50 \pm 0.36$ & \\
\hline$\left[\mathrm{Co}\left(\mathbf{L}_{1}\right)_{2}\left(\mathrm{H}_{2} \mathrm{O}\right)_{2}\right] \mathrm{Cl}_{2}$ & $21.30 \pm 0.50$ & $19.60 \pm 0.21$ & $18.20 \pm 0.36$ & $24.40 \pm 0.54$ & \\
\hline$\left[\mathrm{Co}_{2}\left(\mathbf{L}_{1}\right)_{4}\left(\mathbf{L}_{2}\right)\left(\mathrm{H}_{2} \mathrm{O}\right)_{2}\right] \mathrm{Cl}_{4}$ & $24.50 \pm 0.30$ & $24.40 \pm 0.45$ & $26.50 \pm 0.36$ & $25.60 \pm 0.43$ & In this work \\
\hline$\left[\mathrm{Co}\left(\mathbf{L}_{1}\right)_{2}\left(\mathbf{L}_{2}\right)\left(\mathrm{H}_{2} \mathrm{O}\right)\right] \mathrm{Cl}_{2}$ & $29.60 \pm 0.23$ & $29.30 \pm 0.69$ & $32.20 \pm 0.15$ & $29.60 \pm 0.26$ & \\
\hline$\left[\mathrm{Co}_{2}(\text { Phen })_{4}(\mathrm{Act})_{2}(\mathrm{en}) \mathrm{Cl}_{4}\right.$ & $34 \pm 0.06$ & $40 \pm 0.06$ & $15 \pm 0.00$ & $17 \pm 0.10$ & \multirow[t]{2}{*}[12]{} \\
\hline$\left[\mathrm{Co}(\text { Phen })_{2}(\right.$ Act $)($ en $\left.)\right] \mathrm{Cl}_{2}$ & $14 \pm 0.06$ & $12 \pm 0.15$ & $12 \pm 0.00$ & $16 \pm 0.06$ & \\
\hline$\left[\mathrm{Co}_{2}\left(\mathbf{A}_{1}\right)_{4}\left(\mathbf{A}_{2}\right)_{2}\left(\mathbf{A}_{3}\right)\right] \mathrm{Cl}_{4}$ & $23.25 \pm 0.66$ & -- & -- & $23.76 \pm 0.57$ & [1] \\
\hline$\left[\mathrm{Co}\left(\mathbf{A}_{1}\right)_{2}\left(\mathbf{A}_{2}\right)\left(\mathrm{H}_{2} \mathrm{O}\right)\right] \mathrm{Cl}_{2}$ & $19.53 \pm 0.50$ & -- & -- & $21.33 \pm 0.57$ & \\
\hline$\left[\mathrm{Co}(\mathrm{Phen})_{2}(\mathrm{Cyt})\left(\mathrm{H}_{2} \mathrm{O}\right)\right] \mathrm{Cl}$ & $25.3 \pm 1.15$ & -- & $28.0 \pm 1.00$ & $32.3 \pm 0.57$ & {$[18]$} \\
\hline
\end{tabular}

Key: en= Ethylenediamine, 2,2'-bipy=2,2'-bipyridine, IZ=inhibition zone, $E$. coli =Escherichia-coli, $K$. pneumoniae $=$ Klebsiella pneumoniae, S. pyogenes $=$ Streptococcus pyogenes and $S$.

aureus $=$ Staphylococcus aureus. $(\mathrm{A} 1=1,10$-phenanthroline, A2 = adenine, A3 = 1,3-diaminepropane).

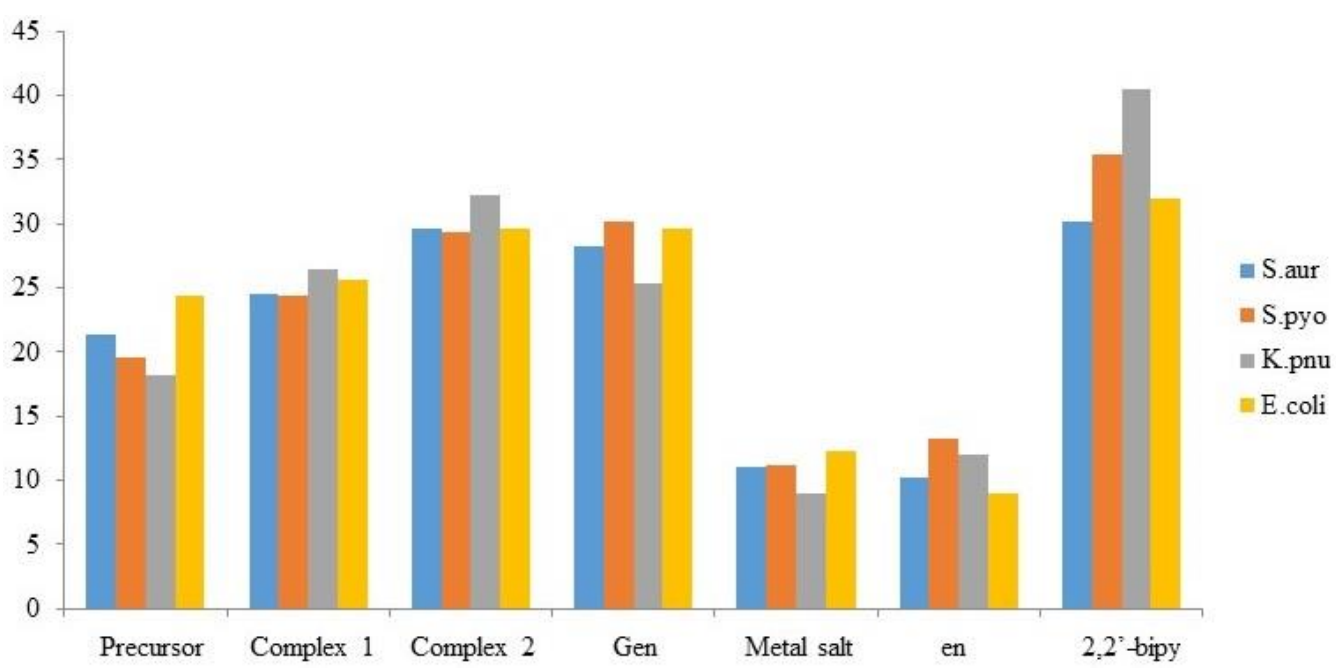

Figure 5. Comparison of antibacterial activity of $\mathrm{CoCl}_{2} \cdot 6 \mathrm{H}_{2} \mathrm{O}$, ligands, metal complexes, and gentamycin.

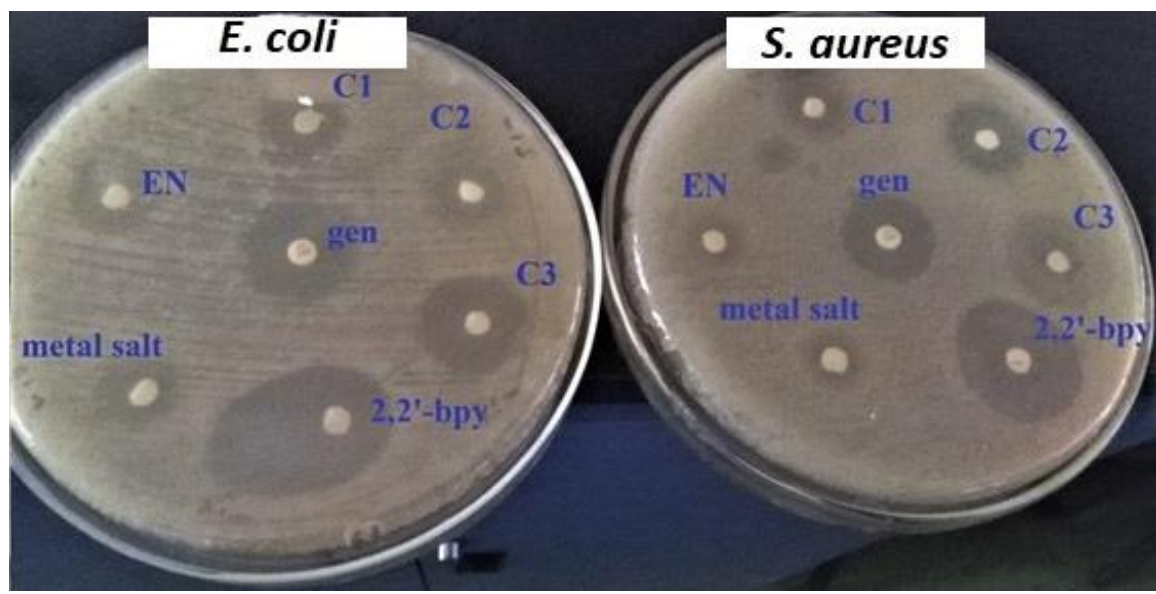

Figure 6. The inhibition observed by the actions of complexes and commercially available antibiotics on and Gram-negative bacteria $(E$. coli $)$ and Gram-positive bacteria $(S$. aureus $)$. Where $\mathrm{C} 1=\left[\mathrm{Co}\left(\mathrm{L}_{1}\right)_{2}\left(\mathrm{H}_{2} \mathrm{O}\right)_{2}\right] \mathrm{Cl}_{2}, \mathrm{C} 2=$ $\left[\mathrm{Co}_{2}\left(\mathrm{~L}_{1}\right)_{4}\left(\mathrm{~L}_{2}\right)\left(\mathrm{H}_{2} \mathrm{O}\right)_{2}\right] \mathrm{Cl}_{4}, \mathrm{C} 3=\left[\mathrm{Co}\left(\mathrm{L}_{1}\right)_{2}\left(\mathrm{~L}_{2}\right)\left(\mathrm{H}_{2} \mathrm{O}\right)\right] \mathrm{Cl}_{2}, \mathrm{EN}=$ Ethylenediamine, 2,2'-bpy= 2,2'-bipyridine, metal salt $\mathrm{CoCl}_{2} \cdot 6 \mathrm{H}_{2} \mathrm{O}$, and gen $=$ Gentamicin . 
Table 4. percentage activity index data of the complexes against the tested bacteria compared Gentamycin.

\begin{tabular}{l|c|c|c|c}
\multirow{2}{*}{ Complexes } & \multicolumn{3}{|c}{ \%activity index of Co(II) complexes } \\
\cline { 2 - 5 } & S. aureus & S. pyogenes & $\begin{array}{c}\text { K. } \\
\text { pneumoniae }\end{array}$ & E.coli \\
\hline$\left[\mathrm{Co}\left(\mathbf{L}_{1}\right)_{2}\left(\mathrm{H}_{2} \mathrm{O}\right)_{2}\right] \mathrm{Cl}_{2}$ & $-24.7 \%$ & $-35.7 \%$ & $-28 \%$ & $-17.6 \%$ \\
\hline$\left[\mathrm{Co}_{2}\left(\mathbf{L}_{1}\right)_{4}\left(\mathbf{L}_{2}\right)\left(\mathrm{H}_{2} \mathrm{O}\right)_{2}\right] \mathrm{Cl}_{4}$ & $-13.4 \%$ & $-20.0 \%$ & $4.7 \%$ & $-13.5 \%$ \\
\hline$\left[\mathrm{Co}\left(\mathbf{L}_{1}\right)_{2}\left(\mathbf{L}_{2}\right)\left(\mathrm{H}_{2} \mathrm{O}\right)\right] \mathrm{Cl}_{2}$ & $4.5 \%$ & $-3.9 \%$ & $27.3 \%$ & $0.3 \%$
\end{tabular}

3.5.1. Minimum inhibitory concentration (MIC).

The minimum inhibitory concentration (MIC) is the lowest concentration of the antimicrobial agent that prevents viable growth after overnight incubation. The minimum inhibitory concentration (MIC) of complex 1 was determined by introducing seven different concentrations (700, 500, 300, 250, 200, and 150 and $100 \mathrm{mg} / \mathrm{L})$. The lowest concentration of the complex that inhibited the growth of the test organism was taken as the minimum inhibitory concentration. The result shows the complex starts to inhibit around $100 \mathrm{ppm}$ on $K$. pneumoniae and $250 \mathrm{ppm}$ on the rest of the bacteria, as shown below in Table 5.

Table 5. The minimum inhibitory concentration of complex $\mathbf{1}$ at different concentrations in $(\mathrm{mg} / \mathrm{L})$.

\begin{tabular}{c|c|c|c|c|c|c|c}
\multirow{2}{*}{ Microbes } & \multicolumn{7}{|c}{ Growth observation for each concentration (mg/L) } \\
\cline { 2 - 8 } & $\mathbf{7 0 0}$ & $\mathbf{5 0 0}$ & $\mathbf{3 0 0}$ & $\mathbf{2 5 0}$ & $\mathbf{2 0 0}$ & $\mathbf{1 5 0}$ & $\mathbf{1 0 0}$ \\
\hline S. aureus & - & - & - & + & + & + & + \\
\hline S. pyogenes & - & - & - & + & + & + & + \\
\hline E.coli & - & - & - & + & + & + & + \\
\hline K. pneumoniae & - & - & - & - & - & - & +
\end{tabular}

Key: (-) no bacteria growth, (+) bacteria growth.

\section{Conclusions}

In this work, two new cobalt complexes were synthesized and characterized. The physicochemical and spectroscopic data suggest that $\mathrm{Co}$ (II) and the ligands are brought together with rigid configuration, and hence both the complexes proposed octahedral geometry. The comparative antibacterial activity study of the complexes revealed the potential of ligands in tailoring the activities. The results provide new insights on metal-based drugs, particularly coordinating with ligands such as ethylenediamine in a different fashion. Thus the overall biological findings of this work would be useful in improving the effectiveness of therapeutic drugs. Based on the observations, the in vivo shall be investigated as a continuation of this study.

\section{Funding}

This research has no funds.

\section{Acknowledgments}

The authors thank Bahir Dar University, Ethiopia, and Jeonbuk National University, Republic of Korea, for providing facilities for characterization and for performing an antimicrobial test of the complexes.

\section{Conflicts of Interest}

The authors declare no conflict of interest. 


\section{References}

1. Abebe, A.; Bayeh, Y.; Belay, M.; Gebretsadik, T.; Thomas, M.; Linert, W. Mono and binuclear cobalt (II) mixed ligand complexes containing 1, 10-phenanthroline and adenine using 1, 3-diaminopropane as a spacer: synthesis, characterization, and antibacterial activity investigations. Future J. Pharm. Sci. 2020, 6, 1-9, https://doi.org/10.1186/s43094-020-00030-4.

2. Abebe, A. and Hailemariam, T. Synthesis and assessment of antibacterial activities of ruthenium (III) mixed ligand complexes containing 1, 10-phenanthroline and guanide. Bioinorg chem appl, 2016, 2016, 3607924, https://doi.org/10.1155/2016/3607924.

3. Smitten, K.L.; Southam, H.M.; de la Serna, J.B.; Gill, M.R.; Jarman; P.J.; Smythe, C.G.; Poole, R.K.; Thomas, J.A. Using nanoscopy to probe the biological activity of antimicrobial leads that display potent activity against pathogenic, multidrug-resistant, gram-negative bacteria. ACS nano 2019, 13, 5133-5146, https://doi.org/10.1021/acsnano.8b08440.

4. Eleraky, N.E.; Allam, A.; Hassan, S.B.; Omar, M.M. Nanomedicine Fight against Antibacterial Resistance: An Overview of the Recent Pharmaceutical Innovations. Pharmaceutics 2020, 12, 1-51, https://doi.org/10.3390/pharmaceutics12020142.

5. Mahapatra, D.K.; Bharti, S.K.; Asati, V.; Singh, S.K. Perspectives of medicinally privileged chalcone-based metal coordination compounds for biomedical applications. Eur. J. Med. Chem. 2019, 174, 142-158, https://doi.org/10.1016/j.ejmech.2019.04.032.

6. Vamsikrishna, N.; Daravath, S.; Ganji, N.; Pasha, N. Synthesis, structural characterization, DNA interaction, antibacterial and cytotoxicity studies of bivalent transition metal complexes of 6-aminobenzothiazole Schiff base. Inorg. Chem. Commun. 2020, 113, 107767, https://doi.org/10.1016/j.inoche.2020.107767.

7. Arunadevi, A.; Porkodi, J.; Ramgeetha, L.; Raman, N. Biological evaluation, molecular docking and DNA interaction studies of coordination compounds gleaned from a pyrazolone incorporated ligand. Nucleosides, Nucleotides, and Nucleic Acids 2019, 38, 656-679, https://doi.org/10.1080/15257770.2019.1597975.

8. Abebe, A.; Tamiru, G. A hexacationic coordination compound from Co (II) and a cationic ligand derived from 4, 4'-bipyridine: Synthesis, characterization, and investigation for biological application. Cogent Chem. 2018, 4, 156-162, https://doi.org/10.1080/23312009.2018.1564162.

9. Kumar, M.; Mogha, N.K.; Kumar, G.; Hussain, F.; Masram, D.T. Biological evaluation of copper (II) complex with nalidixic acid and 2, 2'-bipyridine (bpy). Inorganica Chim. Acta 2019, 490, 144-154, https://doi.org/10.1016/j.ica.2019.03.011.

10. Shaikh, I.; Jadeja, R.N.; Patel, R. Three mixed ligand mononuclear Zn (II) complexes of 4-acyl pyrazolones: Synthesis, characterization, crystal study and anti-malarial activity. Polyhedron 2020, 183, 114528, https://doi.org/10.1016/j.poly.2020.114528.

11. Ashraf, R.; Bhatti, H.N.; Iqbal, M.A.; Jamil, Y. Synthesis of aryl linked binuclear silver N-heterocyclic carbene complexes, DNA interaction study and biological potentials. Inorg. Chem. Commun. 2020, 119, 108077, https://doi.org/10.1016/j.inoche.2020.108077.

12. Tamiru, G.; Abebe, A.; Abebe, M.; Liyew, M. Synthesis, structural investigation and biological application of new mono-and binuclear cobalt (II) mixed-ligand complexes containing 1, 10-phenanthroline, acetamide, and ethylenediamine. Ethiop. J. Sci. Technol. 2019, 12, 69-91, https://doi.org/10.4314/ejst.v12i1.4.

13. Shahabadi, N.; Mahdavi, M.; Momeni, B.Z. Two novel bipyridine-based cobalt (II) complexes: synthesis, characterization, molecular docking, DNA-binding, and biological evaluation. J. Biomol. Struct. Dyn. 2020, 39, 595-609, https://doi.org/10.1080/07391102.2020.1713893.

14. Eremina, J.A.; Lider, E.V.; Samsonenko, D.G.; Sheludyakova, L.A.; Berezin, A.S.; Klyushova, L.S.; Ostrovskii, V.A.; Trifonov, R.E. Mixed-ligand copper (II) complexes with tetrazole derivatives and 2, 2'bipyridine, 1, 10-phenanthroline: Synthesis, structure and cytotoxic activity. Inorganica Chim. Acta 2019, 487, 138-144, https://doi.org/10.1016/j.ica.2018.12.011.

15. Aramesh-Boroujeni, Z.; Jahani, S.; Khorasani-Motlagh, M.; Kerman, K.; Aramesh, N.; Asadpour, S.; Noroozifar, M. Experimental and theoretical investigations of Dy (III) complex with 2, 2'-bipyridine ligand: DNA and BSA interactions and antimicrobial activity study. J Biomol Struct Dyn. 2020. 38, 4746-4763, https://doi.org/10.1080/07391102.2019.1689170.

16. Serra-Burriel, M.; Keys, M.; Campillo-Artero, C.; Agodi, A.; Barchitta, M.; Gikas, A.; Palos, C.; LópezCasasnovas, G. Impact of multi-drug resistant bacteria on economic and clinical outcomes of healthcareassociated infections in adults: Systematic review and meta-analysis. PloS one. 2020, 15, e0227139, https://doi.org/10.1371/journal.pone.0227139. 
17. Shalash, A.M.; Ali, H.I.A. Synthesis, crystallographic, spectroscopic studies and biological activity of new cobalt (II) complexes with bioactive mixed sulindac and nitrogen-donor ligands. Chem. Cent. J. 2017, 11, 40, https://doi.org/10.1186/s13065-017-0268-2.

18. Atakilt, A.; Bayissa, G.; Sendek, A.; Kibret, M. Cobalt (II) complexes with 1, 10-phenanthroline alone and mixed with cytoside: Synthesis and antibacterial activities. Ethiop. J. Sci. Technol. 2018, 11, 79-96, https://doi.org/10.4314/ejst.v11i2.1.

19. Murcia, R.A.; Leal, S.M.; Roa, M.V.; Nagles, E.; Muñoz-Castro, A.; Hurtado, J.J. Development of antibacterial and antifungal triazole chromium (III) and cobalt (II) complexes: synthesis and biological activity evaluations. Molecules 2018, 23, 2013, https://doi.org/10.3390/molecules23082013.

20. Schöne, S.; Radoske, T.; März, J.; Stumpf, T.; Ikeda-Ohno, A. Synthesis and Characterization of Heterometallic Iron-Uranium Complexes with a Bidentate N-Donor Ligand (2, 2'-Bipyridine or 1, 10Phenanthroline). Inorg. Chem. 2018, 57, 13318-13329, https://doi.org/10.1021/acs.inorgchem.8b01868.

21. Avcı, D.; Altürk, S.; Sönmez, F.; Tamer, Ö.; Başoğlu, A.; Atalay, Y.; Kurt, B.Z.; Dege, N. A novel series of mixed-ligand M (II) complexes containing 2, 2'-bipyridyl as potent $\alpha$-glucosidase inhibitor: synthesis, crystal structure, DFT calculations, and molecular docking. J. Biol. Inorg. Chem. 2019, 24, 747-764, https://doi.org/10.1007/s00775-019-01688-9.

22. Gurumoorthy, P.; Ravichandran J.; Rahiman A.K. Mixed-ligand binuclear copper (II) complex of 5methylsalicylaldehyde and 2, 2'-bipyridyl: Synthesis, crystal structure, DNA binding, and nuclease activity. Chem. Sci. 2014, 126, 783-792, https://doi.org/10.1007/s12039-014-0607-y.

23. Li, R.Y.; Liu, H.T.; Zhou, C.C.; Chu, Z.T.; Lu, J.; Wang, S.N.; Jin, J.; Yan, W.F. Ligand substitution induced single-crystal-to-single-crystal transformations in two $\mathrm{Ni}$ (II) coordination compounds displaying consequential changes in proton conductivity. Inorg. Chem. Front. 2020, 7, 1880-1891, http://doi:10.1088/1757-899X/359/1/012040.

24. Nworie, F.S. Bis (salicylidene) ethylenediamine (salen) and bis (salicylidene) ethylenediamine-metal complexes: From structure to biological activity. J. anal. pharm. res. 2016, 3, 76-85, http://doi.org/10.15406/japlr.2016.03.00076.

25. Huerta-José, D.S.; Hernández-Hernández, J.G.; Huerta-Aguilar, C.A.; Thangarasu, P. Novel insight of indium (III) complex of N, N'-bis (salicylidene) ethylenediamine as chemo-sensor for selective recognition of HSO4- and hemolytic toxicity (Red Blood Cells) studies: Experimental and theoretical studies. Sens. Actuators B Chem. 2019, 293, 357-365, https://doi.org/10.1016/j.snb.2019.04.011.

26. Albobaledi, Z.; Esfahani, M.H.; Behzad, M.; Abbasi, A. Mixed ligand Cu (II) complexes of an unsymmetrical Schiff base ligand and N-donor heterocyclic co-ligands: Investigation of the effect of co-ligand on the antibacterial properties. Inorganica Chim. Acta 2020, 499, 119185 , https://doi.org/10.1016/j.ica.2019.119185.

27. Gusev, A.N.; Kiskin, M.A.; Braga, E.V.; Chapran, M.; Wiosna-Salyga, G.; Baryshnikov, G.V.; Minaeva, V.A.; Minaev, B.F.; Ivaniuk, K.; Stakhira, P.; Ågren, H. Novel zinc complex with an ethylenediamine Schiff base for high-luminance blue fluorescent OLED applications. J. Phys. Chem. C. 2019, 123, 11850-11859, https://doi.org/10.1021/acs.jpcc.9b02171.

28. Anuja, P.K.; Paira, P. Luminescent anticancer Ru (II)-arenebipyridine and phenanthroline complexes: Synthesis, characterization, DFT studies, biological interactions, and cellular imaging application. J. Inorg. Biochem. 2020, 208, 111099, https://doi.org/10.1016/j.jinorgbio.2020.111099.

29. Jaeger, F.M.; Dijk, J.A. Die verschiedenen Typen von Komplexsalzen des $\alpha$ - $\alpha^{\prime}$-Dipyridyls mit Kupfer, Zink, Cadmium, Eisen, Nickel, Cobalt und Rhodium. Z. anorg. allg. Chem. 1936, 227, 273-327, https://doi.org/10.1002/zaac.19362270308.

30. Bard, A.J.; Faulkner, L.R.; Leddy, J.; Zoski, C.G. ElectrochemicalMethods: Fundamentals and Applications, Wiley, New York, NY, USA 1980.

31. Atkins, P. W. Physical Chemistry, Oxford University Press, Oxford, UK, $5^{\text {th }}$ edition 1994.

32. Ramezani, S.; Pordel, M.; Davoodnia, A. Synthesis, characterization and quantum-chemical investigations of new fluorescent heterocyclic Schiff-base ligands and their cobalt (II) complexes. Inorganica Chim. Acta. 2019, 484, 450-456, https://doi.org/10.1016/j.ica.2018.09.050.

33. Ye, H.; Ren, N.; Li, H.; Zhang, J.; Sun, S.; Tian, L. Synthesis, crystal structure, and thermal decomposition kinetics of complex [Nd (BA) 3bipy] 2.J. Therm. Anal. Calorim. 2010, 101, 205-211, https://doi.org/10.1007/s10973-009-0428-2. 
34. Mohamed, M.S.; Shoukry, A.A.; Ali, A.G. Synthesis and structural characterization of ternary Cu (II) complexes of glycine with 2, 2'-bipyridine and 2, 2'-dipyridylamine. The DNA-binding studies and biological activity. Spectrochim. Acta A Mol. 2012, 86, 562-570, https://doi.org/10.1016/j.saa.2011.11.015.

35. Sadeek, S.A.; Abd El-Hamid, S.M.; El-Shwiniy, W.H. Synthesis, spectroscopic characterization, thermal stability and biological studies of mixed ligand complexes of gemifloxacin drug and 2, 2'-bipyridine with some transition metals. Res. Chem. Intermed. 2016, 42, 3183-3208, https://doi.org/10.1007/s11164-0152205-0.

36. Anjaneyulu, Y.; Rao, R.P. Preparation, characterization, and antimicrobial activity studies on some ternary complexes of $\mathrm{Cu}$ (II) with acetylacetone and various salicylic acids. Synthesis and Reactivity in Inorganic and Metal-Organic Chemistry 1986, 16, 257-272, https://doi.org/10.1080/00945718608057530.

37. Tweedy, B.G. Plant extracts with metal ions as potential antimicrobial agents. Phytopathology 1964, 55, 910914, http://dx.doi.org/10.1094/PDIS-12-15-1416-RE. 